\title{
Gold-specific T Cells in Rheumatoid Arthritis Patients Treated with Gold
}

\author{
P. Romagnoli, G. A. Spinas, ${ }^{\star}$ and F. Sinigaglia \\ Pharma Research Technology, F. Hoffmann-La Roche Limited, CH-4002 Basel, Switzerland; and *Department of Internal Medicine \\ and Research, Kantonsspital, CH-4002 Basel, Switzerland
}

\begin{abstract}
Gold-specific $\mathbf{T}$ lymphocyte clones were isolated from a patient with rheumatoid arthritis who developed delayed type hypersensitivity reactions to gold. All of the isolated $T$ cell clones required histocompatible antigen presenting cells as well as gold for induction of proliferation. Using a panel of HLA-homozygous Epstein Barr virus-transformed B (EBV-B) cells and anti-HLA antibodies, the clones were shown to recognize gold in the context of DR1 molecules. Gold recognition did not require active antigen processing since specific proliferation was not affected by glutaraldehyde fixation of the DR1 homozygous antigen presenting cells. Furthermore, we could show that gold salts inhibited peptide-induced responses of a peptide-specific $T$ cell clone.

In addition to providing evidence for gold-specific $T$ cells in gold-treated RA patients exhibiting delayed type hypersensitivity responses, these data suggest that gold can alter MHC-peptide complexes. The latter observation may in part explain the mechanism/s responsible for both the therapeutic and the toxic effects of gold. (J. Clin. Invest. 1992. 89:254-258.) Key words: antigen presentation $\bullet$ MHC class II molecule $\bullet$ gold $\bullet$ human T cell clones • delayed type hypersensitivity
\end{abstract}

\section{Introduction}

Rheumatoid arthritis is a common autoimmune disease which is characterized by chronic inflammation of the joints. The presence of lymphocytic infiltrates $(1,2)$ and the association of the disease with specific MHC class II determinants (reviewed in 3), which control antigen presentation to $T$ cells, suggest that autoreactive $\mathrm{T}$ lymphocytes may initiate and/or maintain the inflammatory process.

Compounds containing gold in the $\mathrm{Au}(\mathrm{I})$ state, such as gold sodium thiomalate and gold thioglucose, are among a small number of agents which are able to arrest the progression of $\mathrm{RA}^{3}$ and which can even induce remissions in some patients (4-7). However, in up to one-third of the patients treatment has to be stopped because of toxicity (8). The most common

Dr. Romagnoli's present address is National Institutes of Health, Building 10, Room 11N311, Bethesda, MD 20892. Address correspondence to Dr. F. Sinigaglia, Pharma Research Technology, F. Hoffmann-La Roche Ltd., CH-4002 Basel, Switzerland. 1991

Received for publication 6 March 1991 and in revised form 29 July

J. Clin. Invest.

(c) The American Society for Clinical Investigation, Inc.

$0021-9738 / 92 / 01 / 0254 / 05 \quad \$ 2.00$

Volume 89, January 1992, 254-258 toxic effects are delayed type hypersensitivity reactions involving the skin and the mucous membranes (9). Neither the mechanism/s responsible for the therapeutic nor the toxic effects of gold salts have been elucidated (10).

Here we describe the effect of gold on antigen presentation by studying recognition of gold compounds by $T$ cells from RA patients who had developed hypersensitivity reactions to gold, and by examining the effect of gold on peptide presentation to $\mathrm{T}$ cells.

\section{Methods}

Patients. Two patients ( 1 male and 1 female) with RA (A.M. and V.W.) who received gold sodium thiomalate (AuTM), participated in this study after giving informed consent. The patients were 56 and 63 years old and the diagnosis of RA had been made 5 and 12 months earlier according to the 1958 American Rheumatism Association criteria for definite and classical RA.

Patient A.M. received AuTM at an initial dose of $20 \mathrm{mg}$ weekly for the first two weeks followed by $50 \mathrm{mg} / \mathrm{wk}$. After four weeks of therapy the patient developed a pruritic eczematous dermatitis involving the trunk and the extremities. Chrysotherapy was discontinued, and the skin rash resolved completely within two months of onset.

Patient V.W. was also treated with AuTM with $20 \mathrm{mg} /$ wk for the first two weeks and then with $50 \mathrm{mg} / \mathrm{wk}$ for a total of 25 weeks. Thereafter the dosage interval was prolonged to $50 \mathrm{mg} / \mathrm{mo}$. 11 months after initiation of chrysotherapy and having received a cumulative gold dose of $1,440 \mathrm{mg}$ the patient developed a pruritic irregular lichen planus-like rash. Gold therapy was discontinued.

HLA typing. HLA typing was performed by restriction fragment length polymorphism analysis on genomic DNA from EBV-B cells of patient A.M. The class II antigens detected were HLA DR 1,1 and DQw5,w5.

Antigen. Gold thioglucose (AuTG) was obtained from Serva, Heidelberg, FRG, $\mathrm{HAuCl}_{4}$ from Aldrich Chemical Co., Steinheim, FRG, and Tauredon (gold content $46 \%$ ) from Byk Gulden GmbH, Konstanz, FRG, was used as source AuTM.

The recombinant malaria fragment $190 \mathrm{~L}$ used in the fixation experiment was described previously (11).

Culture media. The culture medium RPMI 1640 (Gibco, Paisley, Scotland) was supplemented with L-glutamine ( $2 \mathrm{mM})$, sodium pyruvate $(1 \mathrm{mM}), 5 \times 10^{-5} \mathrm{M} 2$-mercaptoethanol, $1 \%$ of a $100 \times$ mixture of nonessential aminoacids (Gibco), $50 \mathrm{U} / \mathrm{ml}$ penicillin, $50 \mathrm{U} / \mathrm{ml}$ streptomycin, and $10 \%$ heat-inactivated fetal calf serum (RPMI-FCS) or $10 \%$ pooled human AB serum (RPMI-HS). To support the antigen-independent growth of $T$ cell clones, RPMI-HS was supplemented with 100 $\mathrm{U} / \mathrm{ml}$ recombinant human IL2 (rIL2; Hoffmann-La Roche, Inc., Nutley, NJ).

Lymphocyte proliferation assay. $10 \mathrm{ml}$ heparinized whole blood was taken from the two RA patients 1-2 wk after discontinuation of chrysotherapy and PBMC isolated by Ficoll-Hypaque, Pharmacia Fine Chemicals, Uppsala, Sweden. Cells were washed twice, adjusted to a concentration of $4 \times 10^{6} \mathrm{cells} / \mathrm{ml}$ in RPMI-HS and added to wells of 96-well flat-bottomed plates in $100-\mu \mathrm{l}$ vol. Gold compounds at increasing concentrations (ranging from 0.1 to $100 \mu \mathrm{g} / \mathrm{ml}$ ) were added, in triplicate, in 100- $\mu \mathrm{l}$ vol in RPMI-HS. After $5 \mathrm{~d}$ the cultures were pulsed with $1 \mu \mathrm{Ci}$ of $\left[{ }^{3} \mathrm{H}\right]$ thymidine and incorporation was determined after another $16 \mathrm{~h}$. 
Isolation of $T$ cell clones. T cell clones (TLC) ${ }^{1}$ were generated as previously described $(12,13)$. Briefly, PBMC $\left(2 \times 10^{6} / \mathrm{ml}\right)$ were cultured in RPMI-HS for $6 \mathrm{~d}$ with optimal concentration of $\mathrm{HAuCl}_{4}(10$ $20 \mu \mathrm{g} / \mathrm{ml}$ ). Cells were then washed twice, adjusted to a concentration of $4 \times 10^{6}$ cells $/ \mathrm{ml}$ in RPMI-HS and added in duplicate to wells of two separate 96-well flat-bottomed plates (Costar Corp., Cambridge, MA) with irradiated $(5,000 \mathrm{rad})$ autologous PBMC $\left(1 \times 10^{6} / \mathrm{ml}\right)$ in $100-\mu l$ aliquots. $\mathrm{HAuCl}_{4}$ at increasing concentrations (ranging from 0.1 to 10 $\mu \mathrm{g} / \mathrm{ml}$ ) was added in $100-\mu \mathrm{l} \mathrm{vol}$ in RPMI-HS. After $3 \mathrm{~d}$ the cultures of one plate were pulsed with $1 \mu \mathrm{Ci}$ of $\left[{ }^{3} \mathrm{H}\right]$ thymidine, and incorporation of labelled nucleotide was determined after another $16 \mathrm{~h}$. After assessment of antigen-induced proliferation, positive cultures from the duplicate plate were expanded by adding rIL2 and, after another $7 \mathrm{~d}$, cloned by limiting dilution.

For cloning, $\mathrm{T}$ blasts were seeded at $0.3 \mathrm{cell} /$ well in Terasaki trays (Falcon Labware, Becton, Dickinson \& Co., Plymouth, England) in the presence of PHA-P (Wellcome Diagnostics, Dartford, England) at 2 $\mu \mathrm{g} / \mathrm{ml}, 10^{4}$ allogeneic irradiated (5,000 rad), freshly taken, PBMC and rIL2.

Two of the clones (AM1 and AM48) were subcloned at 0.1 cells/ well. The probability of clonality for each subclone was $98 \%$ as determined by Poisson analysis. The subcloning procedure was identical with that described above. The independent clonal origin of TLC AM1 and AM48 was ascertained by genomic Southern blot analysis (EcoRI, BamHII, HindIII) using a human T cell receptor $\beta$ chain constant region probe ( $C \beta 2$ region 0.3 Avall fragment). The clones were expanded and maintained in culture by periodic restimulation $(2-6 \mathrm{wk})$ in the presence of allogeneic irradiated PBMC, $2 \mu \mathrm{g} / \mathrm{ml} \mathrm{PHA}-\mathrm{P}$ and rIL2.

To test the specificity of the $\mathrm{T}$ cell clones in a proliferation assay, cloned $\mathrm{T}$ cells $\left(2 \times 10^{4}\right)$ were cocultured in triplicate with $1 \times 10^{4}$ antigen-presenting cells (APC) (irradiated [7,000 rad] autologous or DR-homozygous Epstein-Barr virus B cells) in $0.2 \mathrm{ml}$ of RPMI-HS with the different gold compounds $(10 \mu \mathrm{g} / \mathrm{ml})$ or without antigen. $\left[{ }^{3} \mathrm{H}\right]$ thymidine incorporation was measured $72 \mathrm{~h}$ later.

TLC AH.L16, used as control in the fixation experiment, recognizes peptide 344-355 of the Plasmodium falciparum blood stage p190 protein and DR1 molecules (14).

The derivation and characterization of the $\mathrm{T}$ cell clone used in the competition assay have been described elsewhere (15).

$E B V-B$ cells used as $A P C$. Epstein-Barr virus-transformed, HLAhomozygous, human $B$ cell lines were used as antigen-presenting cells. The EDR and HOM2 (new designation DRB $1 * 0101$, previous designation DR 1Dw1), NOL (new designation DRB ${ }^{*} 0201$, previous designation DRw15Dw2), AVL (new designation DRB 1*0301, previous designation DRw 17[3]), BSM (new designation DRB 1*0401, previous designation DR4 Dw4), APD (new designation DRB1*1301, previous designation DRw13(6)), EKR (DR7), LUY (DR8) and DKB (new designation DRB1*0901, previous designation DR9) lines were obtained from Dr. A. Termijtelen, University Hospital, Leiden, The Netherlands; PGF (new designation DRB1*1501, previous designation DR2Dw2) and SWEIG (new designation DRBI*1101, previous designation DRw11.1) were obtained from Drs. D. Altmann and S. Marsh (Imperial Cancer Research Fund, London, England).

EBV-B cells from patient A.M. were prepared as described in refs. 12 and 13.

Determination of $T$ cell restriction specificity. The isotype of the class II molecules which were recognized by each $\mathrm{T}$ cell clone was determined by antibody blocking experiments. $\mathrm{T}$ cells were cultured with autologous EBV-B cells, antigen $\left(\mathrm{HAuCl}_{4}\right)$ and anti-DR (E.31) (16), anti-DQ (SVPL3) (17) or anti-DP (B7.21) (18) monoclonal antibodies as 1:100 dilution of ascites. To identify the restricting alleles we used the panel of allogeneic HLA-homozygous EBV-B cells described above as APC. The APC were pulsed for $2 \mathrm{~h}$ at $37^{\circ} \mathrm{C}$ with $20 \mu \mathrm{g} / \mathrm{ml}$ of

1. Abbreviations used in this paper: APC, antigen-presenting cells; SI, stimulation index; TLC, T cell clones.
$\mathrm{HAuCl}_{4}$ or medium alone, washed four times, and irradiated before $\mathrm{T}$ cells were added and proliferation assayed as above.

Glutaraldehyde fixation of $E B V-B$ cells. B cells were fixed as described by Shimonkevitz et al. (19). Briefly, EBV-B cells were sedimented, resuspended in Hanks' medium (Gibco, Paisley, Scotland), and fixed with $0.05 \%$ glutaraldehyde for $1.5 \mathrm{~min}$. The reaction was stopped by adding RPMI-FCS. The cells were sedimented, washed twice, pulsed for $2 \mathrm{~h}$ at $37^{\circ} \mathrm{C}$ with $20 \mu \mathrm{g} / \mathrm{ml}$ of different gold compounds or medium alone, and washed four times before $\mathrm{T}$ cells were added and proliferation assayed as described above.

Effect of gold on peptide- and anti-CD3-induced activation. Competition for antigen presentation has been described elsewhere (20). Briefly, autologous EBV-B cells were fixed by resuspending them in $0.025 \%$ glutaraldehyde for $90 \mathrm{~s}$. The fixation was stopped by addition of $0.2 \mathrm{M}$ glycine and the cells were then resuspended in RPMI 1640 medium containing a cocktail of protease inhibitors and $10 \%$ human serum. Fixed APCs $\left(5 \times 10^{4}\right.$ cells/well $)$ were incubated with a doserange concentration of $\mathrm{Au}(\mathrm{I})$ or $\mathrm{Au}(\mathrm{III})(0.03-30 \mu \mathrm{g} / \mathrm{ml})$ and suboptimal concentration $(1 \mu \mathrm{M})$ of the stimulator peptides specific for the test clones. After incubation for $2-4 \mathrm{~h}$ at $37^{\circ} \mathrm{C}$, the cells were washed three times and cultured with $4 \times 10^{4} \mathrm{~T}$ cells from the $\mathrm{BH} 26$ clone for $48 \mathrm{~h}$. $\left[{ }^{3} \mathrm{H}\right] \mathrm{Thymidine}$ was then added $(1 \mu \mathrm{Ci} /$ well $)$ and its incorporation was measured after $16 \mathrm{~h}$.

The effect of gold on anti-CD3 activation was analyzed by incubating BH26 T-cells $\left(2 \times 10^{4} /\right.$ well $)$ with $1 \times 10^{5}$ irradiated $(5,000 \mathrm{rad})$ allogeneic PBMC in $0.2 \mathrm{ml}$ of RPMI-HS with $10 \mathrm{ng} / \mathrm{ml}$ anti-CD3 (OKT3) and a dose-range concentration of $\mathrm{HAuCl}_{4}$. $\left[{ }^{3} \mathrm{H}\right]$ Thymidine incorporation was measured $72 \mathrm{~h}$ later.

\section{Results}

$\mathrm{HAuCl}_{4}$ and to a lesser extent AuTM and AuTG induced proliferation of PBMC from two RA patients (A.M. and V.W.) who developed hypersensitivity reactions to gold therapy (Table I), but did not induce proliferation of PBMC from either a RA patient on gold therapy but with no gold-induced toxic reactions, or from seven normal individuals (data not shown). The $\mathrm{HAuCl}_{4}$-stimulated cells from donor A.M. were expanded in IL2-containing medium and cloned in the presence of phytohemagglutinin and allogeneic antigen presenting cells as described $(12,13)$. After the cloning procedure cells from 107 wells were assayed for their proliferative response to $\mathrm{HAuCl}_{4}$. Cells from 12 wells proliferated (stimulation index [SI] $>3$ ) in the presence of $\mathrm{HAuCl}_{4}$ and autologous APC. Autologous irra-

Table I. Gold-induced Proliferation of Lymphocytes from Gold-sensitized Patients

\begin{tabular}{|c|c|c|c|c|}
\hline \multirow[t]{2}{*}{ Donor } & \multirow[t]{2}{*}{ Antigen } & \multicolumn{3}{|c|}{ Stimulation index } \\
\hline & & $0.1 \mu \mathrm{g} / \mathrm{ml}$ & $l \mu g / m l$ & $10 \mu \mathrm{g} / \mathrm{ml}$ \\
\hline \multirow{3}{*}{ A.M. } & $\mathrm{AuCl}_{4}^{-}$ & $<2$ & 5.4 & 13.0 \\
\hline & AuTG & $<2$ & $\cdot 3.2$ & 7.3 \\
\hline & AuTM & $<2$ & $<2$ & 3.9 \\
\hline \multirow{3}{*}{ V.W. } & $\mathrm{AuCl}_{4}^{-}$ & $<2$ & 3.0 & 8.9 \\
\hline & AuTG & $<2$ & 3.3 & 4.1 \\
\hline & AuTM & $<2$ & 2.5 & 2.8 \\
\hline
\end{tabular}

Responses (mean of triplicates) are given as stimulation index (ratio of $\left[{ }^{3} \mathrm{H}\right]$ thymidine uptake of PBMC cultured for $6 \mathrm{~d}$ with and without gold compound at stated concentrations). Background values were $632 \mathrm{cpm}$ for PBMC from donor A.M. and $975 \mathrm{cpm}$ for PBMC from donor V.W. 

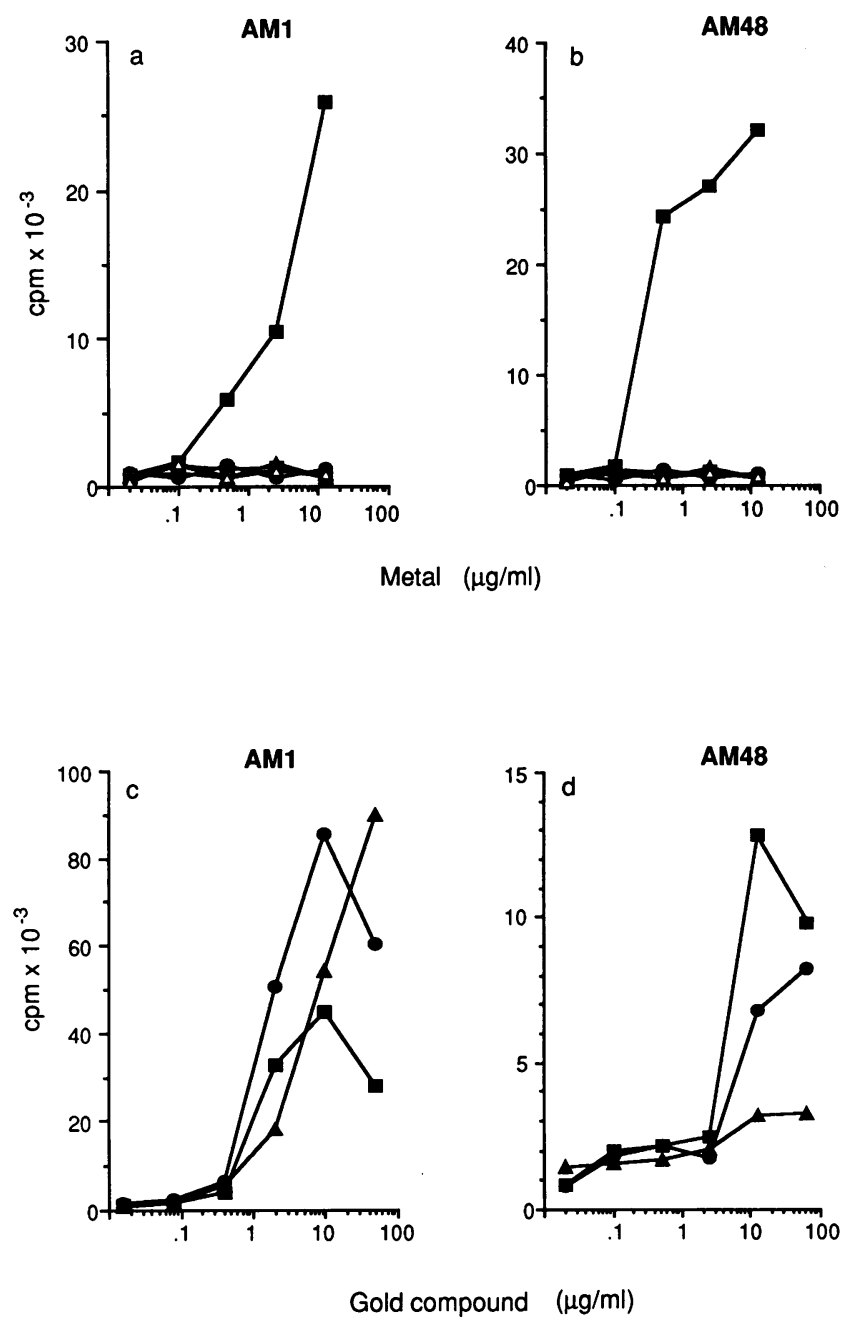

Figure 1. Responses (cpm $\left[{ }^{3} \mathrm{H}\right]$ thymidine uptake) of two $\mathrm{T}$ cell clones from donor A.M. to serial dilutions of $\mathrm{HAuCl}_{4}(\bullet), \mathrm{IrCl}_{3}(\square), \mathrm{OsCl}_{3}$ $(\bullet), \mathrm{RuCl}_{3}(\mathrm{o}), \mathrm{NiSO}_{4}(\Delta), \mathrm{CuSO}_{4}(\Delta)(a$ and $b)$, or to serial dilutions of $\mathrm{HAuCl}_{4}(\bullet), \operatorname{AuTM}(\bullet)$, and AuTG $(\Delta)(c$ and $d)$. diated PBMC and EBV-B cells were equally efficient in stimulating TLC to proliferate to $\mathrm{HAuCl}_{4}$. The remaining cultures did not respond (SI $<1.5$ ). Cells from two wells were subcloned.

Each clone responded equally well to $\mathrm{HAuCl}_{4}$ or AuTM and with varying ability to AuTG but not to other metals: $\mathrm{IrCl}_{3}, \mathrm{OsCl}_{3}, \mathrm{RuCl}_{3}, \mathrm{NiSO}_{4}, \mathrm{CuSO}_{4}$ (Fig. 1). All clones were $\mathrm{CD}^{+}$and $\mathrm{CD} 8^{-}$.

The clones responded to gold only in the presence of appropriate APC. The MHC restriction of the gold-specific T-cell clones was assessed using anti-MHC-class II MAbs. The proliferation of all 12 clones tested was inhibited by the MAb E.31 (16) which recognizes a monomorphic HLA-DR determinant but neither by anti-DP nor by anti-DQ MAbs. The DR restriction specificity of each $T$ cell clone was then determined using a panel of allogeneic HLA-homozygous EBV-B cell lines as APC. All 12 clones tested proliferated in the presence of gold and EBV-B cells expressing DR1, but not in the presence of EBV-B cells that shared no HLA-DR antigens with the $T$ cell donor (Fig. 2). These results indicate that the $T$ cell clones recognize gold in association with the DR 1 molecule.

To determine whether processing was required for gold recognition, glutaraldehyde-fixed APC were tested for their ability to activate the gold-specific $T$ cell clones. In these experiments homozygous DR1 EBV-B cells were fixed with glutaraldehyde and used to stimulate the gold-specific $T$ cell clones and a control DR1 restricted TLC (AH.L16), specific for a malaria p190 peptide (14). Table II shows that gold-specific proliferation was not impaired by fixation of APC while the same fixed APC were incapable of presenting a recombinant malaria polypeptide (14), of 200 amino acids in length, to 190.L-specific T cells. These findings suggested the possibility that gold may directly react with and alter the antigenicity of $\mathrm{MHC}$ antigens or $\mathrm{MHC}$ peptide complexes. We therefore investigated the effect of gold on peptide presentation to $\mathrm{T}$ cells. We used a $\mathrm{T}$ cell clone, $\mathrm{BH} 26$, specific for a malaria circumsporozoite peptide and restricted, like the gold-specific $T$ cell clones, to the HLA-DR 1 allele. APC were pulsed with a particular peptide in the absence
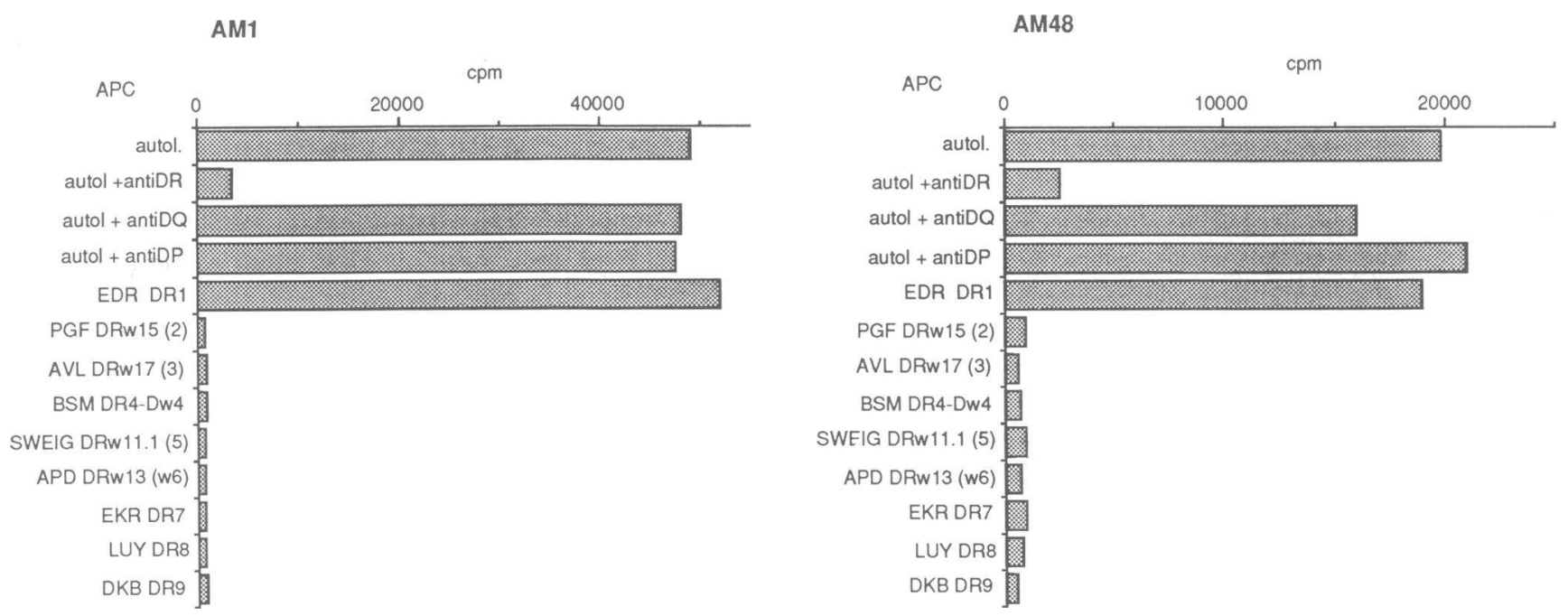

Figure 2. Restriction specificity of gold-specific $\mathrm{T}$ cell clones. Cloned $\mathrm{T}$ cells from donor A.M. were stimulated with $\mathrm{HAuCl}_{4}$ in the presence of autologous or allogeneic HLA homozygous EBV-B cell lines as described in Methods. Results are expressed as mean cpm [ $\left.{ }^{3} \mathrm{H}\right]$ thymidine uptake of triplicate cultures. Anti-HLA antibodies were added to cultures as 1/100 dilution of ascites fluid. AM1 and AM48 T cell clones could also be stimulated by gold presented by the DR1 homozygous EBV-B cell line HOM2 (workshop \#9005) (31). 
Table II. Effect of Fixation on Presentation of Gold to T Cells*

\begin{tabular}{|c|c|c|c|c|}
\hline APC & Antigen & TLC AM1 & TLC AM48 & TLC AH.L16 \\
\hline & & & $c p m \times 10^{-3}$ & \\
\hline Fixed & $\mathrm{HAuCl}_{4}$ & $29.4 \pm 1.6^{\ddagger}$ & $14.3 \pm 0.6$ & $0.3 \pm 0.2$ \\
\hline Irradiated & $\mathrm{HAuCl}_{4}$ & $32.9 \pm 1.3$ & $15.1 \pm 0.9$ & $0.7 \pm 0.3$ \\
\hline Fixed & AuTG & $41.0 \pm 0.9$ & $7.1 \pm 0.4$ & $0.2 \pm 0.3$ \\
\hline Irradiated & AuTG & $44.9 \pm 1.2$ & $8.9 \pm 0.8$ & $0.7 \pm 0.2$ \\
\hline Fixed & AuTM & $44.2 \pm 1.4$ & $11.3 \pm 0.5$ & $0.3 \pm 0.1$ \\
\hline Irradiated & AuTM & $59.4 \pm 1.0$ & $22.7 \pm 0.7$ & $1.2 \pm 0.2$ \\
\hline Fixed & 190.L & $0.1 \pm 0.3$ & $0.3 \pm 0.3$ & $0.3 \pm 0.1$ \\
\hline Irradiated & 190.L & $0.7 \pm 0.1$ & $0.8 \pm 0.2$ & $44.0 \pm 1.5$ \\
\hline Fixed & 190.L (344-355) & $0.3 \pm 0.2$ & $0.2 \pm 0.1$ & $42.3 \pm 1.1$ \\
\hline Irradiated & 190.L (344-355) & $0.5 \pm 0.0$ & $0.7 \pm 0.1$ & $41.9 \pm 1.3$ \\
\hline Fixed & - & $0.3 \pm 0.1$ & $0.3 \pm 0.3$ & $0.4 \pm 0.1$ \\
\hline Irradiated & - & $0.8 \pm 0.2$ & $0.9 \pm 0.2$ & $0.7 \pm 0.1$ \\
\hline
\end{tabular}

* Conditions of assay and glutaraldehyde fixation of antigen presenting cells as described in Methods. ${ }^{\ddagger}$ Responses are given as mean $\mathrm{cpm} \times 10^{-3} \pm \mathrm{SE}\left[{ }^{3} \mathrm{H}\right]$ thymidine uptakes of triplicate cultures after $48 \mathrm{~h}$.

or presence of different concentrations of $\mathrm{HAuCl}_{4}$. After pulsing, the APC were washed and used as stimulator cells for the corresponding $\mathrm{T}$ cell clones. The results of these experiments are shown in Fig. 3. Gold blocked the T cell proliferative response of BH26 T cells. Essentially similar results were obtained with AuTG and AuTM. Inhibition did not result from nonspecific toxic effects, as 50\% inhibition of antigen presentation was attained with only $3 \mu \mathrm{g} / \mathrm{ml}$ of $\mathrm{HAuCl}_{4}$, a concentration lower than the gold dose required for optimal activation of gold-specific $\mathrm{T}$ cells. In addition anti-CD3-induced proliferation of $\mathrm{BH} 26 \mathrm{TLC}$ was not affected by $\mathrm{HAuCl}_{4}$.

\section{Discussion}

Gold salts have long been used to slow or stop the progression of RA (4-7). Although different mechanisms have been proposed, based upon various effects of gold compounds observed in a number of different model systems (reviewed in 10), an adequate explanation for the therapeutic effect and/or the toxic reactions has remained elusive. Since autoreactive $T$ cells are thought to initiate and maintain chronic inflammatory synovitis in rheumatoid arthritis, it seems reasonable to suggest that the therapeutic effect of gold compounds is based on their ability to modify immunological processes (21).

In recent years considerable progress has been made in understanding the recognition of antigens by $T$ cells. The $T$ cell receptors interact with complexes which are formed by antigen fragments and MHC class I or class II molecules (22-27). The recognition of this complex by $\mathrm{T}$ cells is required for the generation of an immune response. It is possible that gold suppresses immune responsiveness by altering MHC-peptide complexes. Therefore we have studied the recognition of gold compounds by $T$ cells. Our study shows that lymphocytes of patients who developed toxic skin reactions to gold proliferate in vitro when challenged with different gold compounds.

The $\mathrm{T}$ cell response to gold does not seem to be due to in vitro priming as suggested to occur in other systems $(15,28)$. In fact no response to gold was obtained with PBMC of several healthy controls as well as with PBMC of a RA patient on gold therapy but with no gold-induced toxic reactions (data not shown).

Gold-specific T cell clones respond to gold (I) (AuTG and $\mathrm{AuTM})$ as well as gold (III) $\left(\mathrm{HAuCl}_{4}\right)$. Since the most common oxidation state of gold in the presence of proteins containing thiols is gold (I) (29), we propose that in our culture conditions gold-specific $T$ cells recognize gold in the oxidation state of gold (I). This view is further supported by the finding that preincubation of gold (III) with a fivefold molar excess of the strong reducing agent glutathione did not affect the ability of the gold to stimulate gold-specific clones (data not shown). These findings are difficult to reconcile with studies by Schuhmann et al. suggesting that gold (III) but not gold (I) was responsible for the capacity to sensitize $T$ cells in an animal model (30).

Gold could generate the stimulatory structure(s) for T cells either by modifying antigens before their association with the presenting class II molecules or by modification of preformed MHC-peptide complexes. To distinguish between these two possibilities we have examined the ability of EBV-B cells to
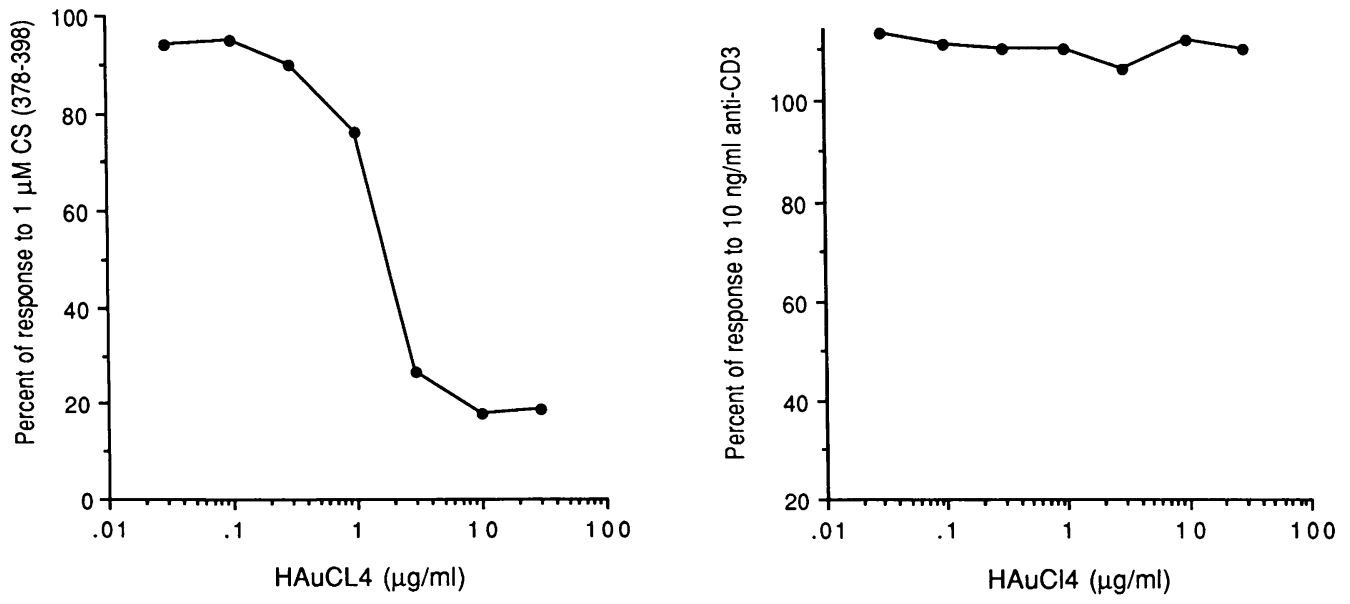

Figure 3. Inhibitory effect of gold on peptide- and antiCD3-induced activation of $\mathrm{T}$ cell clone $\mathrm{BH} 26$. Inhibition of $T$ cell activation was determined as described in Methods. Data are presented as percentage $\left[{ }^{3} \mathrm{H}\right]$ thymidine incorporation obtained in response to $1 \mu \mathrm{M}$ peptide $\mathrm{CS}(378-398)$ or $10 \mathrm{ng} / \mathrm{ml}$ anti-CD3. Values shown are from a single, representative experiment. Responses (cpm, mean of triplicates) in the presence or absence of CS(378-398) peptide were 21652 and 345 , respectively, and 86367 and 1353 in the presence or absence of 10 $\mathrm{ng} / \mathrm{ml}$ of anti-CD3. 
present gold before and after their fixation. Interestingly, glutaraldehyde fixation had no effect on the ability of APC to present gold to $T$ cell clones. Since the present observations suggest that gold can bind to and alter preformed MHC-peptide complexes, we investigated whether gold could inhibit the presentation of a known peptide to $T$ cells. The malaria peptide-specific $\mathrm{T}$ cell clone tested was inhibited by gold, consistent with the idea that gold has the ability to alter the stimulatory complex that is recognized by $\mathrm{T}$ cells. This model is attractive as it could provide an explanation for both the therapeutic and the toxic effects of gold treatment. Modification of putative "autoimmune peptide-MHC complexes" by gold would prevent the stimulation of autoaggressive $T$ cells and in turn elicit gold-specific $\mathrm{T}$ cells that could be responsible for the delayed-type hypersensitivity reactions observed in some patients. The inhibitory effect of gold, however, may be more complex than the interpretation given above. Although antiCD3-induced activation was not affected by gold, we cannot as yet rule out the possibility that gold could interfere with other molecules distinct from MHC, but involved in T cell activation. Future experiments will be undertaken to establish the precise inhibitory mechanism of gold on peptide presentation.

\section{Acknowledgments}

We thank O. Olerup for HLA typing; Y. Uematsu for TCR analysis; D. Altmann, S. Marsh, and A. Termijtelen for providing DR-homozygous EBV-B cell lines used in this study; H. Spits for antibody SPVL3; A. Wolfer for technical assistance; and W. Haas, P. Matzinger, J.R.L. Pink, and M. Steinmetz for criticism and suggestions.

\section{References}

1. Froland, S. S., J. B. Natvig, and G. Busby. 1973. Immunological characterization of lymphocytes in synovial fluid from patients with rheumatoid arthritis. Scand. J. Immunol. 2:67-73.

2. Van Boxel, J. A., and S. A. Paget. 1975. Predominantly T-cell infiltrate in rheumatoid synovial membranes. $N$. Engl. J. Med. 293:517-520.

3. Todd, J. A., H. Acha-Orbea, J. I. Bell, N. Chao, Z. Fronek, C. O. Jacob, M. McDermott, A. A. Sinha, L. Timmerman, L. Steinman, and H. O. McDevitt. 1988. A molecular basis for MHC Class II associated autoimmunity. Science (Wash. DC). 240:1003-1009.

4. Cooperating Clinics Committee of the American Rheumatism Association. 1973. A controlled trial of gold salt therapy in rheumatoid arthritis. Arthritis Rheum. 16:353-358.

5. Research Subcommittee of the Empire Rheumatism Council. 1960. Gold therapy in rheumatoid arthritis. Report of a multi center controlled trial. Ann. Rheum. Dis. 19:95-119.

6. Research Subcommittee of the Empire Rheumatism Council. 1961. Gold therapy in rheumatoid arthritis. Final report of a multi center controlled trial. Ann. Rheum. Dis. 20:315-334.

7. Sigler, J. W., G. B. Bluhm, H. Duncan, J. T. Sharp, D. C. Ensign, and W. R. McCrum. 1974. Gold salts in the treatment of rheumatoid arthritis. A double blind study. Ann. Intern. Med. 80:21-26.

8. Freyberg, R. H. 1950. Present status of gold therapy for rheumatoid arthritis. JAMA (J. Am. Med. Assoc.). 143:418-421.

9. Sigler, J. W. 1983. Parental gold in the treatment of rheumatoid arthritis. Am. J. Med. 75:59-62.
10. Lipsky, P. E. 1983. Remission-inducing therapy in rheumatoid arthritis. Am. J. Med. 75:40-49.

11. Sinigaglia, F., B. Takacs, H. Jacot, H. Matile, J. R. L. Pink, A. Crisanti, and H. Bujard. 1988. Nonpolymorphic regions of p190, a protein of the Plasmo dium falciparum erythrocytic stage, contain both $\mathrm{T}$ and B cell epitopes. J. Immunol. 140:3568-3572.

12. Sinigaglia, F., M. Guttinger, D. Gillessen, D. M. Doran, B. Takacs, H. Matile, A. Trzeciak, and J. R. L. Pink. 1988. Epitopes recognized by human T lymphocytes on malaria circumsporozoite protein. Eur. J. Immunol. 18:633636.

13. Sinigaglia, F., P. Romagnoli, M. Guttinger, B. Takacs, and J. R. L. Pink. 1991. Selection of T-cell epitopes and vaccine engineering. Methods Enzymol. 203:370-386.

14. Sinigaglia, F., M. Guttinger, P. Romagnoli, and B. Takacs. 1990. Malaria antigens and MHC restriction. Immunol. Lett. 25:265-270.

15. Sinigaglia, F., M. Guttinger, J. Kilgus, D. M. Doran, H. Matile, H. Etlinger, A. Trzeciak, D. Gillessen, and J. R. L. Pink. 1988. A malaria T-cell epitope recognized in association with most mouse and human MHC class II molecules. Nature (Lond.). 336:778-780.

16. Trucco, M. M., G. Garotta, J. W. Stocker, and R. Ceppellini. 1979. Murine monoclonal antibodies against HLA structures. Immunol. Rev. 47:219-252.

17. Spits, H., J. Borst, M. Giphart, J. Coligan, C. Terhorst, and J. E. De Vries. 1984. HLA-DQ antigens can serve as a recognition elements for human cytotoxic T lymphocytes. Eur. J. Immunol. 14:299.

18. Watson, A. J., R. DeMars, I. S. Trowbridge, and F. H. Bach. 1983. Detection of a novel class II HLA antigen. Nature (Lond.). 304:358-361.

19. Shimonkevitz, R., J. Kappler, P. Marrack, and H. Grey. 1983. Antigen recognition by $\mathrm{H}-2$ restricted T cells. I. Cell-free antigen processing. J. Exp. Med. 158:303-316.

20. Kilgus, J., P. Romagnoli, M. Guttinger, D. Stuber, L. Adorini, and F. Sinigaglia. 1989. Vaccine T-cell epitope selection by a peptide competition assay. Proc. Natl. Acad. Sci. USA. 86:1629-1633.

21. Lipsky, P. E., and M. Ziff. 1977. Inhibition of antigen- and mitogen-induced human lymphocyte proliferation by gold compounds. J. Clin. Invest. 59:455-466

22. Schwartz, R. H. 1985. T-lymphocyte recognition of antigen in association with gene products of the MHC-complex. Annu. Rev. Immunol. 3:237-261.

23. Zinkernagel, R. M., and P. C. Doherty. 1974. Restriction of in vitro T cell-mediated cytotoxicity in lymphocytic choriomeningitis within a syngeneic or semiallogeneic system. Nature (Lond.). 248:701-702.

24. Matzinger, P. 1981. A one-receptor view of T-cell behaviour. Nature (Lond.). 292:497-501.

25. Townsend, A. R. M., J. Rothbard, F. M. Gotch, G. Bahadur, D. Wraith, and A. J. McMichael. 1986. The epitopes of influenza nucleoprotein recognized by cytotoxic $\mathrm{T}$ lymphocytes can be defined with short synthetic peptides. Cell. 44:959-968.

26. Babbit, B. P., P. M. Allen, G. R. Matsueda, E. Haber, and E. R. Unanue. 1985. Binding of immunogenic peptides to Ia-histocompatibility molecules. $\mathrm{Na}$ ture (Lond.). 317:359-361.

27. Buus, S., A. Sette, S. M. Colon, C. Miles, and H. Grey. 1987. The relation between major histocompatibility complex (MHC) restriction and the capacity of Ia to bind immunogenic peptides. Science (Wash. DC). 235:1353-1358.

28. Pappas, A., C. E. Orfanos, and R. Bertram. 1970. Non-specific lymphocyte transformation in vitro by nickel acetate. J. Invest. Dermatol. 55:198-202.

29. Shaw, F. C., III. 1979. The mammalian biochemistry of gold: an inorganic perspective of chrysotherapy. Inorg. Perspect. Biol. Med. 2:287-355.

30. Schuhmann, D., M. Kubicka-Muranyi, J. Mirtscheva, J. Gunter, P. Kind, and E. Gleichmann. 1990. Adverse immune reactions to gold. I. Chronic treatment with an $\mathrm{Au}(\mathrm{I})$ drug sensitizes mouse $\mathrm{T}$ cells not to $\mathrm{Au}(\mathrm{I})$, but to $\mathrm{Au}(\mathrm{III})$ and induces autoantibodies formation. J. Immunol. 145:2132-2139.

31. Yang, S. Y., E. Milford, U. Hammerling, and B. Dupont. 1987. Description of the reference panel of B-lymphoblastoid cell lines for factors of the HLA system: the B-cell line panel designated for the tenth international histocompatibility workshop. In Immunobiology of HLA Histocompatibility Testing. Vol. 1. B. Dupont, editor. Springer-Verlag, Berlin, Heidelberg, New York. p. 72. 